\title{
SENSITIVITY OF NEISSERIA GONORRHOEAE TO \\ PARTIALLY PURIFIED R-TYPE PYOCINES AND A POSSIBLE APPROACH TO EPIDEMIOLOGICAL TYPING
}

\author{
C. Caroline Blackwell, $\mathrm{H}$. Young and Isabel Anderson* \\ Department of Bacteriology, Edinburgh University Medical School, Teviot Place, Edinburgh \\ EH8 $9 A G$, and ${ }^{*}$ Westminster Medical School, Horseferry Road, London SWIP $2 A R$
}

A RAPID, inexpensive typing system for Neisseria gonorrhoeae would be of use in epidemiological studies, for distinguishing failures of treatment from cases of reinfection, and in the early recognition of strains that might have special pathogenic features such as those associated with disseminated infection (Knapp and Holmes, 1975; Morello, Lerner and Bohnoff, 1976; Schoolnick, Buchanan and Holmes, 1976; Eisenstein, Lee and Sparling, 1977). Previous efforts to type gonococcal strains have involved the serological detection of antigenic differences (Glynn and Ward, 1970; Maeland, Kristoffersen and Hofstad, 1971; Apicella, 1974; Johnston, Holmes and Gotschlich, 1976; Tramont et al., 1976; Wang et al., 1977), differences in nutritional requirements (Carifo and Catlin, 1973) and variations in sensitivity to bacteriocines (Flynn and McEntegart, 1972; Walstad, Reitz and Sparling, 1974; Knapp, Falkow and Holmes, 1975; Lawton et al., 1976).

Observations on the production of pyocines and demonstration of sensitivity to these bacteriocines have been used as the basis of typing systems for Pseudomonas aeruginosa (Farmer and Herman, 1969; Govan and Gillies, 1969). Sensitivity to R-type pyocines has been reported for strains of $N$. gonorrhoeae (Morse et al., 1976) and the possible use of pyocines as a typing tool has been investigated (Sidberry and Sadoff, 1977). Three types of bacteriocines have been described in Ps. aeruginosa: soluble bacteriocines (S-type) similar to the colicines of Escherichia coli (Ito, Kageyama and Egami, 1970), rod-type (R-type) particles resembling defective bacteriophages (Kageyama, 1964), and the flexuous F-type bacteriocines (Govan, 1974b). The R-type and F-type pyocines were chosen for the present study because they can be sedimented by ultracentrifugation and are visible in electron micrographs; these qualities allow their partial purification and separation from the S-type pyocines and other soluble inhibitory substances produced by Ps. aeruginosa.

Using 23 pyocine preparations, Sidberry and Sadoff (1977) obtained 30 sensitivity patterns among 106 strains of $N$. gonorrhoeae but the majority of the strains fell into two groups and further evaluation of the method with gonococcal isolates from several sources was suggested by the authors. 


\section{MATERIALS AND METHODS}

Micro-organisms and culture media. Strains of Ps. aeruginosa producing the R-type pyocines listed in table I were obtained from Dr John Govan of this department. Kageyama (1975) classified many R-type pyocines on the basis of their spectrum of activity, and strains from groups R1, R2, R3 and R5 were specifically chosen for use in this study. The Kageyama classification for the R-type pyocines produced by these strains is given when known. Strains of Ps. aeruginosa from which F-type pyocines were obtained were pp430, F1, R186, Ep520, Ep111, R34, R7095, Ep274, Ru84, and Ep 397. Strains of Pseudomonas were maintained by subculture on nutrient agar every 7 days. $N$. gonorrhoeae strains were supplied by the Center for Disease Control (CDC), Atlanta, Ga, USA and the Royal Infirmary, Edinburgh (RIE). Organisms from disseminated infections were obtained from Dr Joan S. Knapp, Neisseria Reference Laboratory,

TABLE I

Pyocine-producing strains of Pseudomonas aeruginosa and their corresponding indicator strains

\begin{tabular}{c|cc}
\hline $\begin{array}{c}\text { Kageyama } \\
\text { classification }\end{array}$ & $\begin{array}{c}\text { Pyocine-producing } \\
\text { strain }\end{array}$ & $\begin{array}{c}\text { Pyocine indicator } \\
\text { strain }\end{array}$ \\
\hline R1 & IS4 & ISC \\
& IS6 & ISC \\
& IS8 & ISC \\
& ISD & ISC \\
R2 & 2285 & ISC, IS6 \\
& ISB & ISC \\
R21 & pp430 & IS8 \\
R3 & ISE & IS4 \\
R4 & $\ldots$ & $\ldots$ \\
R5 & ISC & IS4, IS5 \\
Unclassified & R205 & ISC \\
\hline \multicolumn{2}{c}{$\ldots=$ Not available for examination. }
\end{tabular}

United States Public Health Service, Seattle, Washington; these included prototrophic strains and strains of different auxotypes from three geographic areas: Atlanta, Indianapolis, and Seattle. All RIE organisms had been identified as $N$. gonorrhoeae on the basis of Gram stain, oxidase reaction and sugar utilisation. On arrival at our laboratory each was retested for oxidase reaction and Gram staining. Strains were stored in skimmed milk at $-20^{\circ} \mathrm{C}$. The gonococcal strains were maintained on either Thayer Martin medium (TM) or modified New York City medium (MNYC; Young, 1978). When needed, colony types T1, T2, T3 and T4 were selected from GC Medium (Difco) with the aid of a stereoscopic microscope with a double system of substage lighting (Jephcott and Reyn, 1971).

Sensitivities to antibiotics were determined on clear GC Medium (Difco) with the following additions per $960 \mathrm{ml}$ after autoclaving: $0.5 \%$ (w.v) ferric nitrate (British Drug Houses) $10 \mathrm{ml}$, GC supplement $* 20 \mathrm{ml}, 20 \%$ (w.v) glucose $10 \mathrm{ml}$. Antibiotics were added to GC agar at the following concentrations: penicillin G (Glaxo) sodium salt: 0.015, 0.03, 0.06, 0.125, 0.25, 0.5, 1, 2 units $/ \mathrm{ml}$; tetracyline hydrochloride (Achromycin, Lederle Ltd): 0.05, 0.1, 0.25, 0.5, $1 \mu \mathrm{g} / \mathrm{ml}$; spectinomycin hydrochloride (Trobicin, Upjohn Ltd): $2,4,8,16 \mu \mathrm{g} / \mathrm{ml}$; chloramphenicol (Chloromycetin, Parke-Davis Ltd): 0·1, 0.2, 0.4, 0.8, $1.6 \mu \mathrm{g} / \mathrm{ml}$; lincomycin hydrochloride (Upjohn Ltd): 4, 8, 16, $32 \mu \mathrm{g} / \mathrm{ml}$.

* GC supplement: L glutamine (Koch Light Chemicals) 0.5 g, cocarboxylase (British Drug Houses) 0.01 g, water to $100 \mathrm{ml} 20 \%$. 
Antibiotic-sensitivity testing. Visibly turbid suspensions (approximately $1 \times 10^{8}-3 \times 10^{8}$ colony-forming units $/ \mathrm{ml}$ ) of gonococci were made in $\mathrm{NaCl} 0.85 \%$ (w/v) containing soluble starch $1 \%$ (starch-saline). Portions of the suspension were placed in the wells of a Steers replicator which delivered approximately $0.0025 \mathrm{ml}$ of the suspension to the antibiotic plates (Steers, Foltz and Graves, 1959). The same suspensions were also used for the assay of sensitivity to pyocines. The plates were then incubated for $48 \mathrm{~h}$ at $37^{\circ} \mathrm{C}$ with $10 \% \mathrm{CO}_{2}$ in a Searle Qualitemp (80 TC) $\mathrm{CO}_{2}$ incubator. Minimal inhibitory concentration (MIC) was recorded as the lowest concentration of antibiotic at which there were five or fewer colonies per spot inoculated.

Induction and preparation of pyocines. Pyocine preparations were obtained by a modification of the method of Govan (1974a). From an overnight nutrient-broth culture, $2 \mathrm{ml}$ was added to $25 \mathrm{ml}$ of sodium glutamate broth (SGB) which contained sodium glutamate $20 \mathrm{~g}$, glucose $(20 \% \mathrm{w} / \mathrm{v}$ solution) $20 \mathrm{ml}$, magnesium sulphate $\left(\mathrm{MgSO}_{4} 7 \mathrm{H}_{2} \mathrm{O}\right) 0 \cdot 1 \mathrm{~g}$, disodium hydrogen phosphate $\left(\mathrm{Na}_{2} \mathrm{HPO}_{4} .12 \mathrm{H}_{2} \mathrm{O}\right) 5.63 \mathrm{~g}$, potassium dihydrogen phosphate $\left(\mathrm{KH}_{2} \mathrm{PO}_{4}\right) 0.25 \mathrm{~g}$, calcium nitrate $10 \mathrm{mg}$, yeast extract $1 \mathrm{~g}$, and distilled water to 1 litre. The sterile glucose in solution (Seitz filtered) was added to the cooled autoclaved medium before use (Kageyama and Egami, 1962).

The pseudomonads were incubated at $30^{\circ} \mathrm{C}$ in an orbital incubator (Gallenkamp) at 100 r.p.m. for $2.5 \mathrm{~h}$. Mitomycin $\mathrm{C}(1.5 \mu \mathrm{g} / \mathrm{ml})$ was added at this point and the cultures were incubated for another $2 \cdot 5-3 \mathrm{~h}$. The lysates were centrifuged at $10000 \mathrm{~g}$ for $30 \mathrm{~min}$. to remove bacterial cells and debris; each supernatant was decanted, shaken with chloroform $5 \%(v / v)$ and stored at $4{ }^{\circ} \mathrm{C}$. This preparation was the crude pyocine lysate.

The crude lysate $(12.5 \mathrm{ml})$ was ultracentrifuged at $100000 \mathrm{~g}$ for $3 \mathrm{~h}$ and the supernatant containing S-type pyocine activity and other soluble inhibitory substances was discarded. The pellet containing the R-type activity was resuspended in $10 \mathrm{ml} 0.01 \mathrm{M}$ Tris buffer $(p \mathrm{H} \mathrm{7.5)}$ containing $0.01 \mathrm{M} \mathrm{MgCl}_{2} 6 \mathrm{H}_{2} \mathrm{O}$ and $0.01 \mathrm{M} \mathrm{MgSO}_{4} 7 \mathrm{H}_{2} \mathrm{O}$ (referred to hereafter as Tris buffer). This partially purified pyocine preparation was stored at $4^{\circ} \mathrm{C}$.

Assay of pyocine activity against Ps. aeruginosa and $N$. gonorrhoeae. Pyocine activities of the crude lysates and the partially purified preparations were assayed by spotting doubling dilutions on nutrient-agar (NA) plates and MNYC plates and allowing the spots to dry. The NA plates were then flooded with the appropriate standard strains of Ps. aeruginosa (indicator strains) known to be sensitive to the particular test pyocine. Sensitive and resistant gonococcal strains, identified in pilot studies, were tested on MNYC.

Partially purified pyocine lysates were diluted 1 in 2 in Tris buffer and spotted with a dropper pipette calibrated to deliver $0.02 \mathrm{ml}$ on plates of GC, MNYC or TM medium and allowed to dry. Overnight plate cultures of gonococci were suspended in starch-saline and used to flood the plates to produce a confluent lawn. The plates were allowed to dry and incubated overnight at $37^{\circ} \mathrm{C}$ aerobically with $10 \% \mathrm{CO}_{2}$. Some gonococci grew more slowly and were incubated for an additional $24 \mathrm{~h}$. Results were recorded as $t=$ inhibition, $\pm=$ inhibition with some overgrowth, $-=$ no inhibition. Ps. aeruginosa indicator strains were included in each test as well as the gonococcal strains CDC486 or CDC046, which were sensitive to most pyocines tested, and strain 879 which was resistant to most pyocines tested. The sensitivity of a gonococcal strain to each pyocine was examined at least three times. Preparations were assayed regularly to monitor levels of active pyocines. Those with low titres usually gave equivocal or negative results. Table III includes representative data of pyocine titres and sensitivities of sensitive strains CDC486, CDC046 and resistant strain 879.

Serotyping of meningococci and sulphadiazine sensitivity testing were done by Dr R. J. Fallon, Department of Laboratory Medicine, Ruchill Hospital, Glasgow.

\section{Results}

\section{Preliminary studies}

None of the F-type pyocines listed (see Methods) inhibited any of 84 gonococcal strains against which they were tested in pilot studies. Several of the R-type pyocines were able to inhibit $94.5 \%(104 / 110)$ of the gonococcal 
strains selectively. Inhibition was observed on clear GC, TM, or MNYC or media; the darker background of the TM and MNYC plates facilitated readings and these media were less subject to contamination. Addition of $1 \%$ soluble starch or $2 \%$ bovine serum albumin to the GC plates did not affect inhibition of gonococci by the pyocines.

\section{Comparison of sensitivities of different indicators to the test pyocines}

Two types of zones of inhibition corresponding to those found for soluble (S-type) and rod-type (R-type) pyocines were observed with the gonococci. The S-type zones resembled those found with soluble bacteriocines (Fredericq, 1957) or other inhibitory substances that diffuse readily into agar away from the site of inoculation. Large zones of this type were observed with crude lysates. Typical R-type zones-smaller, discrete zones of inhibition limited to the site of inoculation (Ito et al., 1970)-were found with the partially purified ultracentrifuged preparations. Table II illustrates the differences in inhibition produced by crude lysates and the partially purified pyocines. These were titrated against the appropriate Pseudomonas indicators and two gonococcal strains, one that had appeared to be resistant to pyocines tested in the pilot studies and one that appeared to be sensitive to many of the pyocines. Ultracentrifugation separated the heavier R-type particles from the S-type pyocines, pigments, and other soluble substances that had an inhibitory effect on the gonococci. The pyocines in table II were selected as examples of this effect because the partially purified pyocines of Kageyama groups R 2 and R 3 did not inhibit gonococci under the conditions used in the survey but the crude lysates did. These observations are of importance when our results are compared with those of other workers.

The concentration of the gonococcal inoculum usually made little difference to the inhibition observed with a series of twofold dilutions of pyocines up to 1 in 8192. Undiluted gonococcal inocula and tenfold dilutions up to 1 in 100

TABLE II

Titration of crude lysate and ultracentrifuged preparations against Ps. aeruginosa and $N$. gonorrhoeae

\begin{tabular}{|c|c|c|c|c|c|c|c|}
\hline \multirow{2}{*}{\multicolumn{2}{|c|}{$\begin{array}{l}\text { R-type pyocines } \\
\text { from }\end{array}$}} & \multicolumn{6}{|c|}{ Titre of the stated pyocine, preparation in tests with } \\
\hline & & \multicolumn{2}{|c|}{$\begin{array}{l}\text { Pseudomonas } \\
\text { indicator }\end{array}$} & \multicolumn{2}{|c|}{$\begin{array}{l}\text { sensitive } \\
\text { gonococci }\end{array}$} & \multicolumn{2}{|c|}{$\begin{array}{l}\text { resistant } \\
\text { gonococci }\end{array}$} \\
\hline$\overbrace{\text { Kageyama group }}$ & $\overline{\text { strain }}$ & $\begin{array}{c}\text { Crude } \\
\text { pyocine }\end{array}$ & $\begin{array}{l}\text { Ultracentri- } \\
\text { fuged pyocine }\end{array}$ & $\begin{array}{c}\text { Crude } \\
\text { pyocine }\end{array}$ & $\begin{array}{l}\text { Ultracentri- } \\
\text { fuged pyocine }\end{array}$ & $\begin{array}{l}\text { Crude } \\
\text { pyocine }\end{array}$ & $\begin{array}{l}\text { Ultracentri- } \\
\text { fuged pyocine }\end{array}$ \\
\hline $\mathbf{R} 2$ & $\begin{array}{l}\text { ISB } \\
\text { R21 } \\
\text { pp430 }\end{array}$ & $\begin{array}{l}1024 \\
8192 \\
8192\end{array}$ & $\begin{array}{r}128 \\
4096 \\
8192\end{array}$ & $\begin{array}{r}128 \\
128 \\
32\end{array}$ & $\begin{array}{l}1^{*} \\
4 \\
1\end{array}$ & $\begin{array}{l}8 \\
8 \\
8\end{array}$ & $\begin{array}{l}0^{*} \\
0 \\
0\end{array}$ \\
\hline $\mathbf{R 3}$ & ISE & 8192 & 8192 & 32 & 1 & 8 & 0 \\
\hline
\end{tabular}

* $1=$ Undiluted preparation; $0=$ no inhibition. 
were tested. A more dilute suspension occasionally gave a clearer zone of inhibition; strains were retested with diluted suspensions when only faint reactions $( \pm)$ were obtained with undiluted preparations. The partially purified pyocine preparations were diluted in twofold steps to 1 in 8192 and each dilution was spotted on to appropriate plates for assay of inhibitory activity against a known standard sensitive strain of Ps. aeruginosa, a sensitive gonococcal strain and a resistant gonococcal strain. The titres of inhibitory activity for the pyocines of Kageyama groups R1, R2, R3, and R5 and the pyocine that is unclassified are outlined in table III.

TABLE III

Comparative sensitivities of $P$ s. aeruginosa and $N$. gonorrhoeae to partially purified pyocines

\begin{tabular}{|c|c|c|c|c|}
\hline \multicolumn{2}{|c|}{$\begin{array}{l}\text { R-type } \\
\text { from }\end{array}$} & \multicolumn{3}{|c|}{$\begin{array}{l}\text { Titre of the partially purified pyocine } \\
\text { preparation in tests with }\end{array}$} \\
\hline $\begin{array}{l}\text { Kageyma } \\
\text { group }\end{array}$ & strain & $\begin{array}{l}\text { Ps. aeruginosa } \\
\text { indicator }\end{array}$ & $\begin{array}{l}\text { sensitive } \\
\text { gonococci }\end{array}$ & $\begin{array}{l}\text { resistant } \\
\text { gonococci }\end{array}$ \\
\hline R1 & $\begin{array}{l}\text { IS4 } \\
\text { IS6 } \\
\text { IS8 } \\
2285 \\
\text { ISD }\end{array}$ & $\begin{array}{l}8192 \\
8192 \\
8192 \\
8192 \\
1024\end{array}$ & $\begin{array}{r}1024 \\
1024 \\
1024 \\
1024 \\
128\end{array}$ & $\begin{array}{l}0 \\
0 \\
0 \\
1 \\
0\end{array}$ \\
\hline R2 & $\begin{array}{l}\text { ISB } \\
\text { pp430 } \\
\text { R21 }\end{array}$ & $\begin{array}{r}128 \\
8192 \\
4096\end{array}$ & $\begin{array}{l}0 \\
1 \\
4\end{array}$ & $\begin{array}{l}0 \\
0 \\
0\end{array}$ \\
\hline R3 & ISE & 8192 & 1 & 0 \\
\hline R4 & $\ldots$ & $\ldots$ & $\ldots$ & $\ldots$ \\
\hline R5 & ISC & 2048 & 1024 & 0 \\
\hline Unclassified & R205 & 8192 & 1025 & 0 \\
\hline
\end{tabular}

Footnote as in table II.

Group R1. Preparations of pyocines in this group were potent in tests against the sensitive Pseudomonas indicator strain, and less potent against sensitive gonococci strain CDC486 or CDC046, usually by three dilution tubes. There was only a slight inhibition of the "resistant" strain 879 by the undiluted strain 2285 pyocine.

Group R2. Although the titres for pyocines pp430 and R21 on sensitive strains of $P$ s. aeruginosa were similar to those for pyocines for group R1, the sensitivity of gonococci to these pyocines was dramatically lower and not reliably reproducible. The titre for pyocine ISB determined with $P$ s. aeruginosa for this set of tests was lower than that of pp430 or R21 and no inhibition of gonococci was noted. Slight inhibition of the sensitive gonococcal strain was observed with another preparation of pyocine ISB that had a higher titre on the sensitive Pseudomonas indicator, but this was only with the undiluted pyocine. 
Group $R 3$. The only example of this group, pyocine ISE, yielded results similar to those observed with pyocines of group R2 - high titres on tests against the sensitive $P$ s. aeruginosa indicator strain but little or no reproducible activity against gonococci tested.

Group R4. Our collection did not include a member of this group.

Group R5. Results obtained for pyocine ISC were similar to those found for pyocines of group R 1 -high titres on sensitive $P$ s aeruginosa strain and slightly lower titres for sensitive gonococci.

Unclassified. Pyocine R205 was not classifiable in any of the Kageyama groups. Its titres on sensitive strains of Pseudomonas and gonococci were similar to those found for groups R1 and R5.

At the higher dilutions of each pyocine, areas of inhibition of growth became increasingly turbid. Morse et al. (1976) made similar observations and suggested that this was evidence for a non-replicating inhibitory substance. Not all strains were sensitive at the same dilutions of the pyocines; therefore a dilution of 1 in 2 was chosen for the screening procedure. This dilution would provide a large number of pyocine particles and correspond to the dilution used by Sidberry and Sadoff (1977).

\section{Typing of Neisseria spp. with partially purified pyocine preparations}

Isolates from different sites of individual patients as well as isolates from known consorts were tested for sensitivity to pyocines and antibiotics. A typical set of results is presented in table IV. Sensitivities to penicillin G, lincomycin, tetracycline, chloramphenicol, and spectinomycin were determined for each isolate with the same culture suspension that was used for determining pyocine sensitivities. These "matched" isolates usually had very similar pyocine patterns and identical patterns of sensitivities to the above antibiotics. We observed no correlation between patterns of pyocine sensitivities and sensitivity to any particular antibiotic.

In table $\mathrm{V}$ pyocine-sensitivity patterns for CDC and RIE strains are compared. There was a broader distribution of strains than that found by Sidberry and Sadoff (1977). Although there were differences in numbers per pyocine type in the two groups, there were only five small patterns-F, G, I, J and $\mathrm{M}$-that were found among the CDC isolates but not the RIE ones.

Table VI presents pyocine-sensitivity patterns for strains from disseinfections. There were no extraordinary sensitivities, e.g., to pyocines of Kageyama groups R2 or R3. Patterns of sensitivity were not associated with particular sites of isolation, penicillin sensitivity or auxotypes. The majority of strains from each of the three geographic regions had similar patterns.

Strains of Neisseria meningitidis from patients attending the Department of Venereology were also collected and several were tested for sensitivity to pyocines. Only two of those sent for typing were serotypable; strain 1042B was of serotype W135 and strain 1055A was of type $Z^{\prime}$. The majority were serologically nontypable but were of different pyocine types. There were two patients from whom meningococci were isolated from genital sites. Strain 330B was 


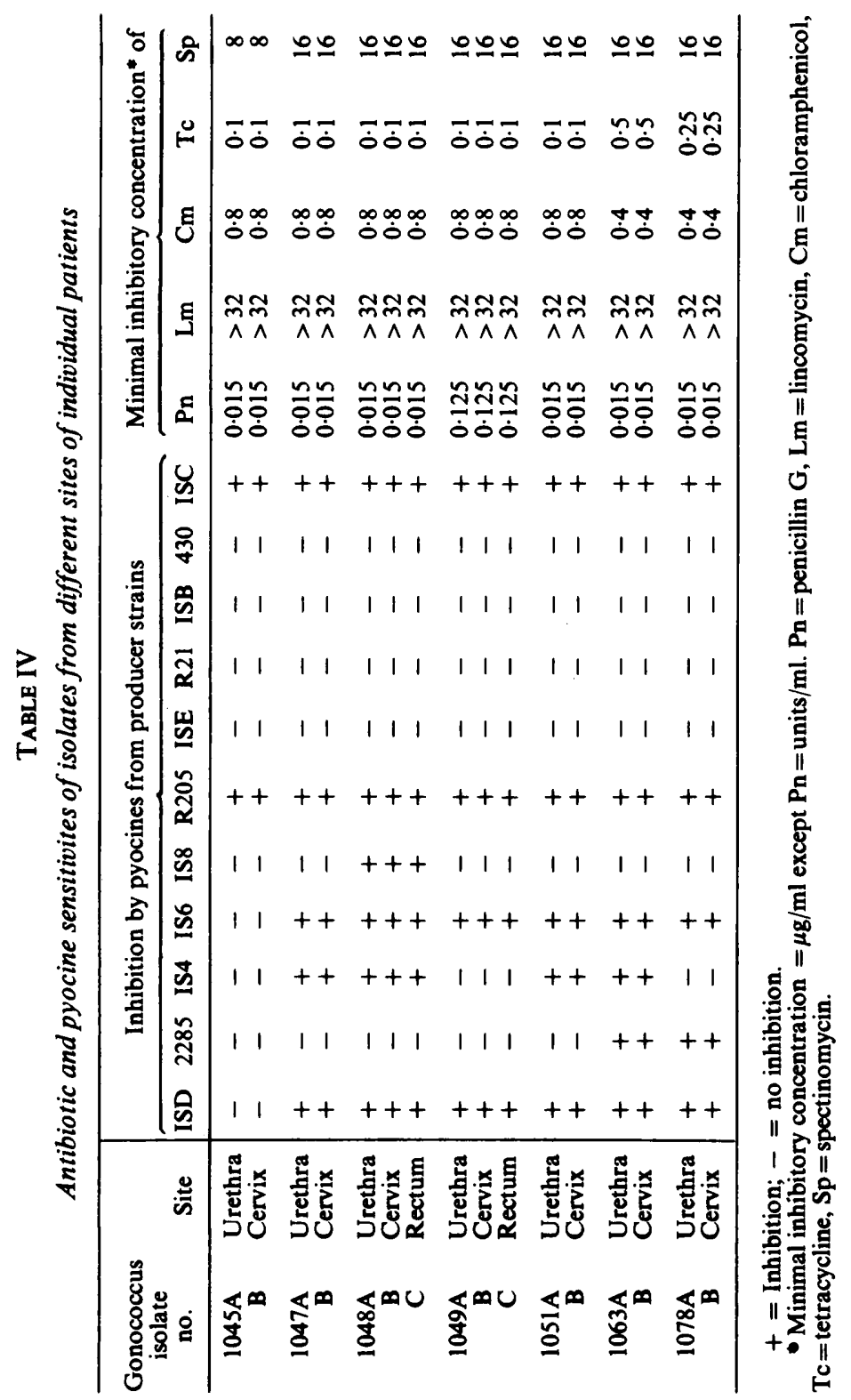




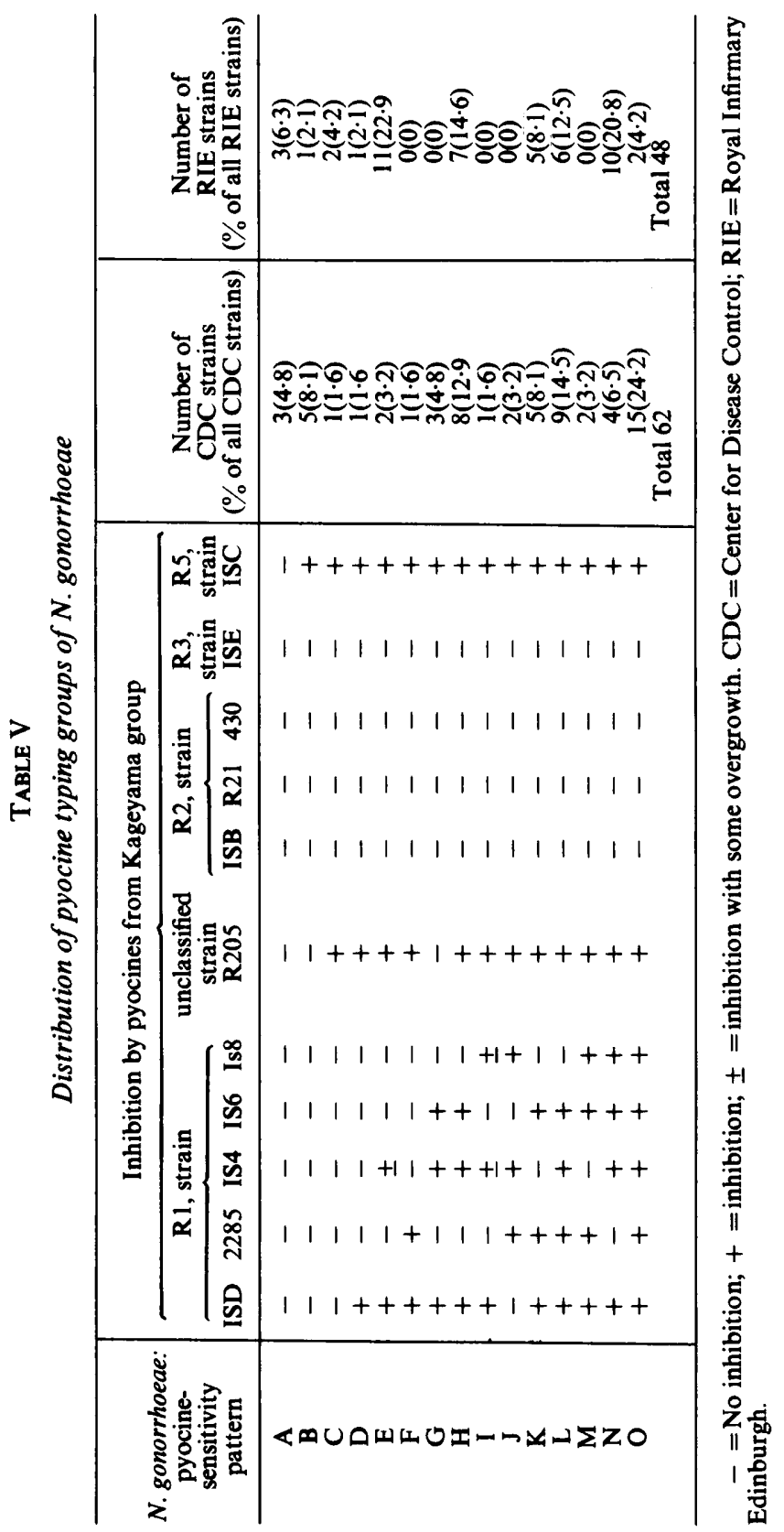




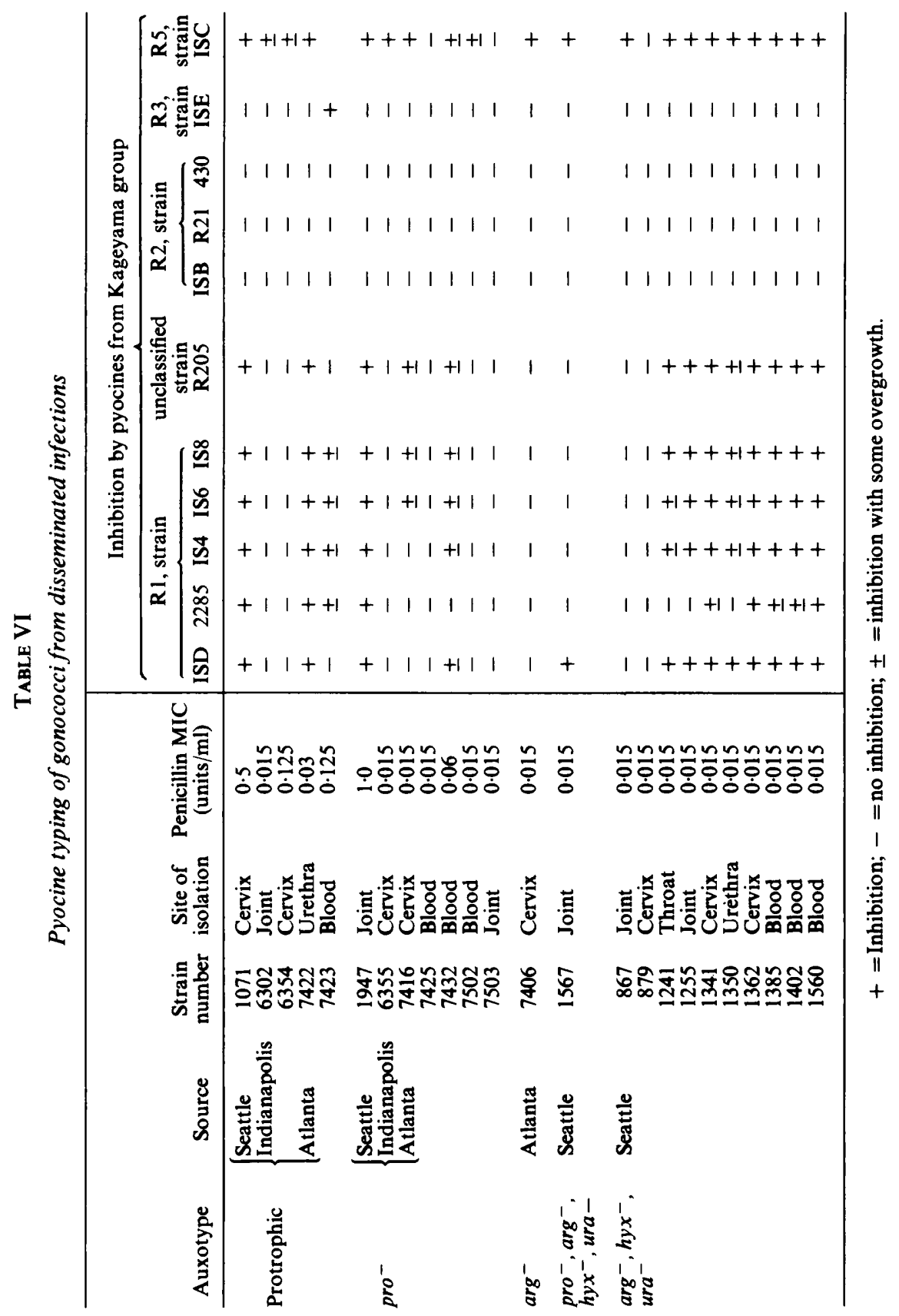




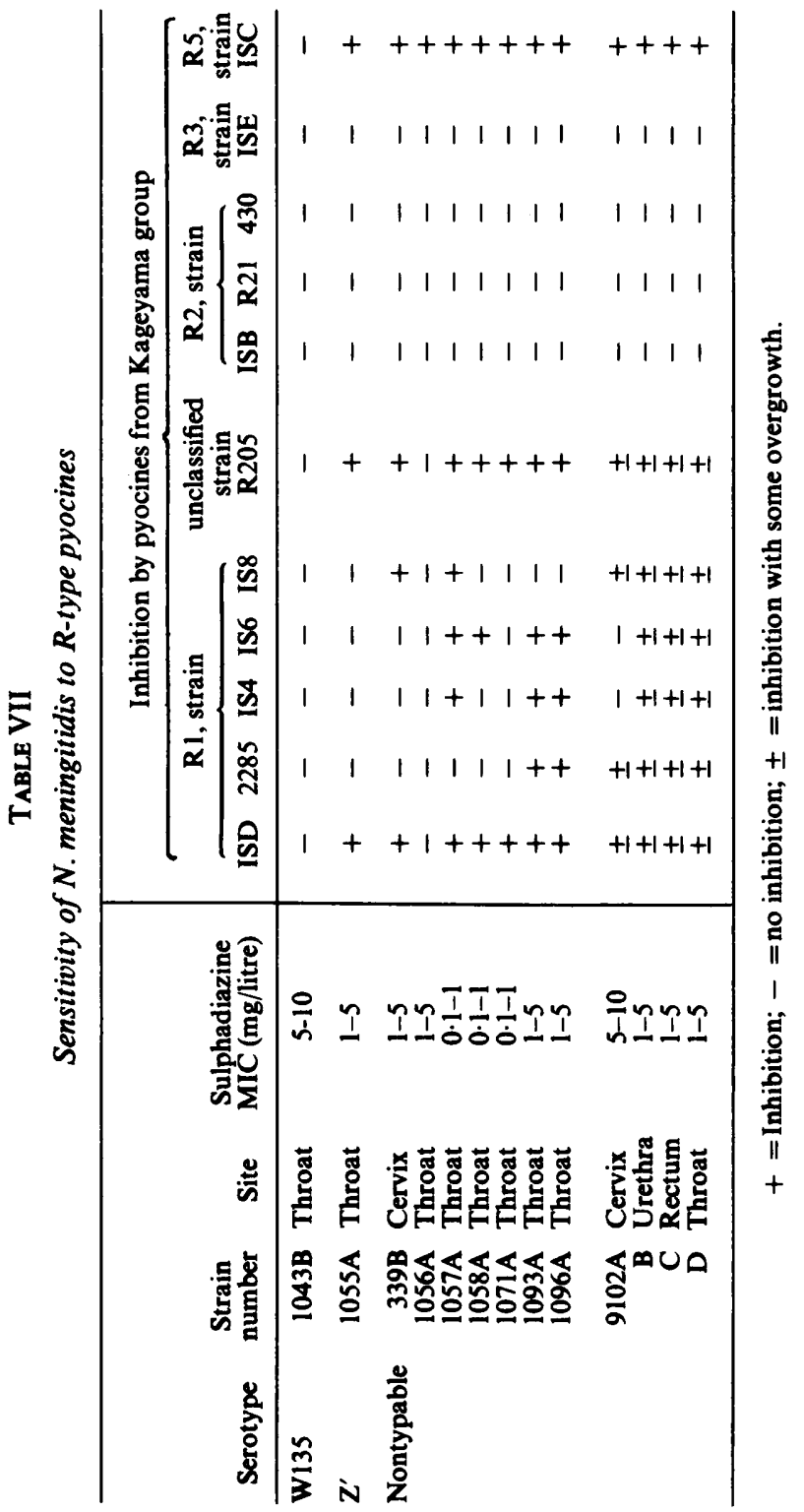


found in a cervical culture and strains $9102 \mathrm{~A}, \mathrm{~B}, \mathrm{C}$, and D from cervix, urethra, rectum, and throat respectively. The genital isolates from these two patients were non-typable serologically and had different pyocine types. Three of the four isolates from patient 9102 had similar patterns of pyocine sensitivity and similar sensitivities to sulphadiazine $(1-5 \mathrm{mg} / \mathrm{ml})$. Strain $9102 \mathrm{~A}$ was less sensitive to sulphadiazine $(5-10 \mathrm{mg} / \mathrm{ml})$ than the other three isolates and had a different pyocine-sensitive pattern (table VII). Further studies are in progress with a larger group of meningococci from different serological groups and sources.

\section{Discussion}

These results are additional evidence that tests for sensitivity of gonococci to R-type pyocines may provide a rapid, simple, inexpensive method for typing $N$. gonorrhoeae (Sidberry and Sadoff, 1977). Isolates from consorts or from different body sites of individual patients could generally be identified as being similar strains. Patterns of antibiotic sensitivities for these matched isolates agreed with the findings for pyocine sensitivities. Sensitivity to pyocines appears to be a stable characteristic. A fresh local isolate and a strain from a disseminated infection, both subcultured twice a week for over a year, have maintained their original patterns of sensitivity to the pyocines tested.

Preliminary results with organisms from several sources (CDC collection) and local isolates indicated that there is a broader distribution among the pyocine sensitivity types of gonococci observed than that found by Sidberry and Sadoff (1977) with their isolates from limited geographical locations. Using 23 pyocine lysates they found 30 types; but a majority of their strains $48 \%(51 / 106)$ fell into one group and $18 \%(19 / 106)$ into a second group. We found 15 types in tests with 11 pyocines and there are several more types to be defined with the additional pyocines being used in our present studies.

Table VIII presents an analysis of our results compared with those of Sidberry and Sadoff (1977). The analysis is based on the schematic representation of pyocine receptors in Ps. aeruginosa proposed by Kageyama (1975). It was observed in our study that if a gonococcal strain was sensitive to any of the pyocines, it was sensitive to ISC, a pyocine of Kageyama group R5; the gonococcal strains in both studies were most often sensitive to members of this group. Fewer strains were inhibited by pyocines of group R1 and the proportions of strains inhibited by this group of pyocines were similar in both studies. Our results differed in that we were unable to detect reproducible inhibition by R2 and R3 pyocines among the gonococcal strains tested. Crude lysates of R2 and R3 pyocines produced large S-type zones of inhibition on the "sensitive" (CDC486) and "resistant" (879) standard strains of gonococci, but the ultracentrifuged preparations did not inhibit either strain. Because the preparations used in Sidberry and Sadoff's studies were equivalent to our crude lysates, some of the inhibition by R2 and R3 pyocines that they observed with a few gonococcal strains may have been due to the presence of material other than the R-type pyocines. 
TABLE VIII

Inhibition of $N$. gonorrhoeae by pyocines of Kageyama groups RI-RS; comparison of results with those of Sidbery and Sadoff (1977)

Percentage of $\boldsymbol{N}$. gonorrhoeae isolates of indicated strain inhibited by pyocines of Kageyama group

\begin{tabular}{|c|c|c|c|c|}
\hline $\mathbf{R} 3{ }^{*}$ & $\mathbf{R} 4^{*}$ & R2* & $\mathbf{R} 1^{*}$ & $\mathbf{R 5}^{*}$ \\
\hline (Sidberr & $H=21 \cdot 8$ & $\begin{array}{l}D=0.9 \\
F=2.8 \\
J=16.4 \\
U=\ldots\end{array}$ & $\begin{array}{l}\mathbf{K}=74 \\
\mathbf{L}=1.9 \\
\mathbf{M}=74.5 \\
\mathbf{N}=76.8 \\
\mathbf{O}=71.7 \\
\mathbf{P}=61.9 \\
Q=5.7 \\
\mathbf{R}=65.1 \\
\mathbf{S}=66.9 \\
T=61.4\end{array}$ & $\begin{array}{l}\mathbf{A}=100 \\
\mathbf{B}=100 \\
\mathbf{C}=100 \\
\mathbf{E}=99 \cdot 1 \\
\mathbf{G}=99 \cdot 1\end{array}$ \\
\hline $\begin{array}{l}\text { ISE }=0 \\
\text { (This stu }\end{array}$ & $\ldots$ & $\begin{array}{l}\text { ISB }=0 \\
\text { R21 }=0 \\
430=0\end{array}$ & $\begin{array}{l}\text { ISD }=84.5 \\
\text { IS4 }=72 \cdot 7 \\
\text { IS6 }=67.3 \\
\text { IS8 }=32.7 \\
2285=42.7\end{array}$ & $I S C=94 \cdot 5$ \\
\hline
\end{tabular}

* Arranged in the order of the receptor sites on the lipopolysaccharide fraction of Ps. aeruginosa suggested by Kageyama (1975); the receptor for R5 is nearest to and that for $\mathrm{R} 3$ is furthest from the cytoplasm.

The receptor site for the R-type pyocines is in the lipopolysaccharide (LPS) (LPS) of Pseudomonas (Ikeda and Egami, 1973; Govan, 1974a; Koval and Meadow, 1977) and a similar location has been suggested for Neisseria (Sidberry and Sadoff, 1977). Table VIII is based on Kageyama's (1975) proposed pyocine receptor sites for his groups R1-R5 in the LPS of Pseudomonas. The receptor for R5 is in the portion of the LPS nearest the cytoplasm. The other receptors, in order towards the most distal portions of the LPS, are R1, R2, R4, $R 3$. The " $R$ " numbers correspond to sites thought to be essential for sensitivity to each pyocine; e.g., mutants lacking the receptor for R3 were resistant to pyocines of the R3 group but sensitive to those of groups R1, R2, R4, and R5. If the receptors for R-type pyocines in Pseudomonas and in gonococci are in the LPS, this analysis suggests a similarity in the "deeper" portions of the LPS of Neisseria and Pseudomonas. Other workers have also found that colony types $\mathrm{T} 1$ and $\mathrm{T} 4$ of the same strain showed no difference in sensitivity to the pyocine R-type 611, 131 (Morse et al., 1976), indicating that pili probably do not form part of the receptor sites for the pyocines examined. The receptors for F-type pyocines are not found in the LPS fractions of Pseudomonas (Govan, 1974b) and, significantly, we did not find any inhibition of gonococci with the 10 F-type pyocines tested.

Gonococci from disseminated infections did not have unique pyocine sensitivities differing from those found for strains from localised infections. 
The sensitivity of Salmonella typhimurium to some bacteriophages depends on the presence of receptor sites in the O repeat units of the LPS. Mutants that have lost these outer portions, rough or R-mutants, are less virulent than the smooth wild type. They are also insensitive to bacteriophages that attack the wild type because they lack the receptor (Rapin and Kalckar, 1971). If there were a unique portion in the outer LPS of the strains from disseminated gonococcal infection that resulted in serum resistance, or increased resistance to phagocytosis, it might be detectable with pyocines. Sensitivity was anticipated to pyocines of Kageyama groups $\mathrm{R} 2$ and/or R3, but no reproducible sensitivities were observed.

These findings are encouraging although further investigation with an emphasis on purification, standardisation and storage of the pyocine preparations used at present is clearly needed. Testing of other pyocines of the various Kageyama groups would be of value. Partially purified preparations of $R 2, R 3$ and R4 pyocines from other sources need to be examined to determine whether there are LPS receptors for these groups or whether the inhibitory effects reported by Sidberry and Sadoff (1977) were due to material other than the R-type pyocines. Pyocines that are "unclassified" by the Kageyama scheme may be useful because we have evidence for the selective inhibition of gonococci by pyocine R205 in the present study. In addition, selection of gonococcal indicator strains will be necessary.

Preliminary experiments indicate that this system may be able to differentiate strains of Neisseria meningitidis that are nongroupable by present serological methods.

\section{SUMMARY}

Strains of Neisseria gonorrhoeae from a variety of sources were examined for sensitivity to 11 partially purified R-type pyocines from Pseudomonas aeruginosa. Selective inhibition of gonococci by pyocines of Kageyama groups R1 and R5 was observed. "Matched isolates", those from consorts or different body sites of individual patients, usually had very similar pyocine-sensitivity patterns and identical sensitivities to five antibiotics tessted. This study included local isolates, strains from diverse geographic regions, and strains from disseminated gonococcal infections. It also proposed a relationship between pyocinereceptor sites in the lipopolysaccharide of Ps. aeruginosa and N. gonorrhoeae. Topics needing further evaluation are discussed.

We are grateful to Anne Lynch and Sheena Tuach for technical assistance and to Professor J. G. Collee and Dr J. R. W. Govan for advice in preparation of the manuscript. We also thank Professor B. P. Marmion for his encouragement and support of the project. This investigation was supported by grant $\mathrm{K} / \mathrm{MRS} / 50 / \mathrm{C} 22$ from the Biomedical Research Committee, Scottish Home and Health Department.

\section{REFERENCES}

ApICella, M. A. 1974. Antigenically distinct populations of Neisseria gonorrhoeae: isolation and characterization of the responsible determinants. J. infect. Dis., 130, 619. 
Carifo, K. AND CatLin, B. W. 1973. Neisseria gonorrhoeae auxotyping: differentiation of clinical isolates based on growth responses on chemically defined media. Appl. Microbiol., 26, 223.

Eisenstein, B. I., LEE, T. J. AND SPARLING, P. F. 1977. Penicillin sensitivity and serum resistance are independent attributes of strains of Neisseria gonorrhoeae causing disseminated gonococcal infection. Infect. Immun., 15, 834.

FARmer, J. J. AND Herman, L. G. 1969. Epidemiological finger-printing of Pseudomonas aeruginosa by the production of and sensitivity to pyocin and bacteriophage. Appl. Microbiol., 18, 760.

FlynN, J. AND MCENTEgART, M. G. 1972. Bacteriocins from Neisseria gonorrhoeae and their possible role in epidemiological studies. J. clin. Path., 25, 60.

FredericQ, P. 1957. Colicins. Ann. Rev. Microbiol. 11, 7.

GLYNN, A. A. AND W ARD, M. E. 1970. Nature and heterogeneity of the antigens of Neisseria gonorrhoeae involved in the serum bactericidal reaction. Infect. Immun., 2, 162.

Govan, J. R. W. 1974a. Studies on the pyocins of Pseudomonas aeruginosa: morphology and mode of action of contractile pyocins. J. gen. Microbiol., 80, 1.

Govan, J. R. W. 1974b. Studies on the pyocins of Pseudomonas aeruginosa: production of contractile and flexuous pyocins in Pseudomonas aeruginosa. J. gen. Microbiol., 80, 17.

Govan, J. R. W. AND GILlIEs, R. R. 1969. Further studies in the pyocine typing of Pseudomonas pyocyanea. J. med. Microbiol., 2, 17.

IKeDA, K. AND EgAM, F. 1973. Lipopolysaccharides of Pseudomonas aeruginosa with special reference to pyocin R receptor activity. J. gen. appl. Microbiol., Tokyo, 19, 115.

ITo, S., KAGEYAMA, M. AND EGAMI, F. 1970. Isolation and characterication of pyocins from several strains of Pseudomonas aeruginosa. J. gen. app. Microbiol., Tokyo, 16, 205.

JePhCOTT, A. E. AND REYN, A. 1971. Neisseria gonorrhoeae. Colony variation I. Acta path. microbiol. scand., B, 79. 609.

Johnston, K. H., Holmes, K. K. AND GotsChLICH, E. C. 1976. The serological classification of Neisseria gonorrhoeae. 1. Isolation of the outer membrane complex responsible for serotypic specificity. J. exp. Med., 143, 741.

Kageyama, M. 1964. Studies of a pyocin. I. Physical and chemical properties. J. Biochem., 55, 49.

Kagey ima, M. 1975. Bacteriocins and bacteriophages in Pseudomonas aeruginosa. In Microbial drug resistance, edited by S. Mitsuhashi and H. Hashimoto. Tokyo, p. 291.

KAGEYAMA, M. AND EGAMI, F. 1962. On the purification and some properties of a pyocin, a bacteriocin produced by Pseudomonas aeruginosa. Life. Sci. Oxford, 9, 471.

KNAPP, J. S., Falkow, S. AND Holmes K. K. 1975. Re-evaluation of bacteriocinogeny in Neisseria gonorrhoeae. J. clin. Path., 28, 274.

KNAPP, J. S. AND HolmEs, K. K. 1975. Disseminated gonococcal infections caused by Neisseria gonorrhoeae with unique nutritional requirements. J. infect. Dis., 132, 204.

Koval, S. F. AND MEADOW, P. M. 1977. The isolation and characterization of lipopolysaccharide-defective mutants of Pseudomonas aeruginosa PAC 1. J. gen. Microbiol., 98, 387.

Lawton, W. D., Bellinger, M. A., Schling, M. and GaAfar, H. A. 1976. Bacteriocin production by Neisseria gonorrhoeae. Antimicrob. Agents Chemother., 10, 417.

MAelAND, J. A., KRISTOFFersen, T. AND HofstAd, T. 1971. Immunochemical investigations on Neisseria gonorrhoeae endotoxin. 2. Serological multispecificity and other properties of phenol-water preparations. Acta path. microbiol. scand., B, 79: 233.

Morello, J. A., LeRner, S. A. AND BoHNOF, M. 1976. Characteristics of atypical Neisseria gonorrhoeae from disseminated and localized infections. Infect. Immun., 13, 1510.

Morse, S. A., Vaughan, P., Johnson, D. AND Iglewiski, B. H. 1976. Inhibition of Neisseria gonorrhoeae by a bacteriocin from Pseudomonas aeruginosa. Antimicrob. Agents Chemother., 10, 354.

RAPIN, A. M. C. AND KALCKAR, H. 1971. The relation of bacteriophage attachment to lipopolysaccharide structure. In Microbiol Toxins, vol IV, edited by G. Weinbaum, S. Kadis, and S. J. Ajl, New York, p. 263. 
Schoolnik, G. K., Buchanan, T. M. and Holmes, K. K. 1976. Gonococci causing disseminated gonococcal infection are resistant to the bactericidal action of normal human sera. J. clin. Invest., 58, 1163.

SidberRy, H. D. AND SADOFF, J. C. 1977. Pyocin sensitivity of Neisseria gonorrhoeae and its feasibility as an epidemiological tool. Infect. Immun., 15, 628 .

SteERS, E., Foltz, E. L. AND GraVES, B. S. 1959. An inocula replicating apparatus for routine testing of bacterical susceptibility to antibiotics. Antibiotics Chemother, 1954-1968, 9, 307.

Tramont, E. C., Griffiss, J. McL., Rose, D., Brooks, G. F. and Artenstein, M. S. 1976. Clinical correlation of strain differentiation of Neisseria gonorrhoeae. J. infect. Dis., 134, 128.

Walstad, D. L., Reitz, R. C. AND Sparling, P. F. 1974. Growth inhibition among strains of Neisseria gonorrhoeae due to production of inhibitory free fatty acids and lysophosphatidylethanolamine: absence of bacteriocins. Infect. Immun., 10, 481 .

Wang, S. P., Holmes, K. K., KnapP, J. S., OtT, S and D. D. Kyzer,, 1977. Immunological classification of Neisseria gonorrhoeae with microimmunofluorescence. J. Immunol., 119, 795.

Young, H. 1978. Cultural diagnosis of gonorrhoea with modified New York City (MNYC) medium. Br. J. vener. Dis., 54, 36. 